\title{
Melt compositions and eruptive conditions inferred from the petrology of Dutoitspan kimberlite
}

\author{
R. Ogilvie-Harris ${ }^{1}$, R.S.J. Sparks ${ }^{1}$, M.J. Walter ${ }^{1} \&$ M. Field ${ }^{2}$ \\ ${ }^{1}$ Department of Earth Sciences, University of Bristol, Bristol, BS8 1RJ, UK, \\ ${ }^{2}$ MRM Group, Mendip Court, Bath Road, Wells, Someset, BA5 3DG, UK
}

\section{Introduction}

The Dutoitspan kimberlite rocks, D2 Type 3, are relatively 'fresh' hypabyssal kimberlite rocks (Clement 1982). The D2 kimberlite contains fresh olivine that has undergone partial alteration along the margin of the crystals and in fractures. Olivine crystals are set in a fine-grained matrix that consists of abundant fresh monticellite, apatite, phlogopite, spinel, calcite, perovskite, and serpentine. The composition of the groundmass is an important factor in determining the compositions of the erupted melts, a major control on the properties of the erupting system.

Kimberlite magmas are explosive and travel to the surface at high speeds. Several process occur during their ascent including: assimilation of the mantle and crustal minerals, decompression, degassing and crystallisation. The rate of eruption and modes of emplacement are influenced greatly by the volatile content of the kimberlite magma. The true contents and solubility of the volatiles are not well constrained, but the abundance of primary phlogopite, monticellite and probable igneous calcite in the D2 kimberlite indicates that these magmas contained significant volumes of water and $\mathrm{CO}_{2}$ (Sparks et al. 2006, references there in)

Constraining the intensive variables (e.g. $f \mathrm{O}_{2}$ and $T$ ) of kimberlite magmas can increase the understanding of mantle-derived processes and conditions. Oxygen fugacity $\left(f \mathrm{O}_{2}\right)$ determines the relative $\mathrm{Fe}^{3+} / \mathrm{Fe}^{2+}$ ratio in coexisiting melts so $\mathrm{fO}_{2}$ can be used as a record for the oxidation levels of the terrestrial magma (Bellis and Canil 2007, refs there in). The variations in $f \mathrm{O}_{2}$ of the magma can be recorded in perovskite, a common accessory phase. $\mathrm{Fe}^{3+}$ is preferentially paritioning into the perovskite structure under relatively low pressure. The $f \mathrm{O}_{2}$ of the kimberlite is calculated by using an equation developed by Bellis and Canil (2007):

$$
\begin{gathered}
\triangle N N O=-[0.50( \pm 0.021) * N b-F e( \pm 0.031) \\
+0.030( \pm 0.001)] / 0.004( \pm 0.0002)
\end{gathered}
$$

(Fe and $\mathrm{Nb}$ are in cation units per 3 oyxgens; uncertainties are given at $2 \sigma$ )

\section{Methodology}

Two standard thin sections of a relatively fresh character were used to study the mineralogy and petrology of the groundmass. 17 different representative areas were selected. Each area was mapped out using an SEM to determine the volume percentage of each mineral present. Image analysis software was used to determine the modal proportions of each mineral present in the groundmass. The chemistry of each mineral was determined by electron microanalysis to help estimate the groundmass element composition for each individual area.

\section{Groundmass Petrology}

D2 kimberlite is a monticellite kimberlite that carries no diamonds. Monticellite is the most abundant groundmass phase, $~ 33 \%$ (Fig. 2), occuring mainly in segregations around large xenoliths. Monticellite inclusions (fresh and altered) are also enclosed in large poikilitic apatite. The euhedral to subhedral grains (15 $\mu \mathrm{m}-50 \mu \mathrm{m})$ can reach up to $120 \mu \mathrm{m}$ toward the edge of the segregations.

Phlogopite, 24 vol\% (Fig. 2), occurs as anhedral basal plates and groundmass stubby laths $(10 \mu \mathrm{m}-300$ $\mu \mathrm{m})$. In some rare cases, larger phlogopite crystals can be seen forming around the outline of the olivine crystals, indicating phlogopite crystallised from the kimberlite magma.

Apatite, 19 vol\% (Fig. 2), is a late crystallising phase that occurs as either large poikilitic crystals $(<300 \mu \mathrm{m})$ or small $(\sim 25 \mu \mathrm{m})$ discrete crystals. Some poikilitic crystals stretch across the monticellite segregation areas and enclose $\mathrm{Cr}$-spinel, perovskite and monticellite (both altered and fresh).

Calcite, $\sim 11$ vol\% (Fig. 2), occurs in two different forms: euhedral and platey or irregular-shaped (bloblike), commonly surrounded by serpentine. The euhedral platey calcite crystals have sharper edges than the irregular elongated calcite crystals $(<6.4 \mathrm{~mm}$ diameter). Calcite tends to crystallise in areas that are monticellite-free along the edges of apatite.

Perovskite, $\sim 4$ vol\% (Fig. 2), is an equant accesory mineral that occurs in two different parageneses: 1) within the groundmass of the kimberlite or 2) enclosed in poikilitic apatite. Perovskite crystals $(<75 \mu \mathrm{m})$ are zoned and range mainly between $15 \mu \mathrm{m}$ to $30 \mu \mathrm{m}$. It is common for perovskite to be intergrown with spinel. The contact formed with spinel normally preserves the grain edge perfecly where the two minerals have crystallised simultaneously (Fig. 1). 


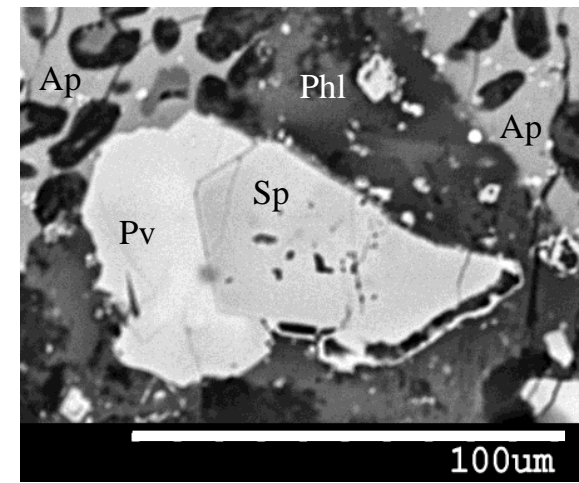

Fig. 1 Perfect contact preserved where the perovskite encloses the chrome spinel; an Fe-rich rim has formed where the (lower) edge of the spinel has been exposed to the kimberlite fluid; Pv-perovskite; Sp-spinel; Ap - Apatite; Phl-phlogopite

Spinel, 7.7 vol\% (Fig. 2), can be found enclosed within poikilitic apatites, the phlogopite and serpentine matrix or as a 'necklace' (with perovskite) around the edges of altered xenoliths. The spinel crystals are zoned and commonly have $\mathrm{Cr}$-rich cores and $\mathrm{Fe}$-rich rims (atoll texture). Crystals $(<65 \mu \mathrm{m})$ are typically 20 $\mu \mathrm{m}$ to $30 \mu \mathrm{m}$.

\begin{tabular}{cccc}
\hline Mineral & $\mathbf{( 1 )}$ & $\mathbf{( 2 )}$ & $\mathbf{( 3 )}$ \\
\hline Monticellite & 11.48 & 23.50 & 33.25 \\
Apatite & 6.62 & 13.56 & 19.70 \\
Calcite & 3.70 & 7.58 & 10.83 \\
Phlogopite & 8.28 & 16.96 & 24.54 \\
Cr spinel & 0.98 & 2.00 & 2.83 \\
Fe spinel & 1.68 & 3.45 & 4.87 \\
Perovskite & 1.36 & 2.79 & 3.98 \\
Serpentine & 14.73 & 30.17 & - \\
Alt Olivine* & 20.84 & - & - \\
Olivine & 30.33 & - & - \\
\hline
\end{tabular}

Fig. 2 Table showing the average volume percentages of each mineral in D2 kimberlite. (1) Vol \% of minerals in the whole rock; (2) Vol \% of the minerals in the groundmass including serpentine (only groundmass); (3) Vol \% of the minerals in the groundmass excluding serpentine.

* Alt olivine - serpentine associated with olivine crystals

\section{Modal proportions}

The modal proportions of the kimberlite rocks were calculated using the average compositions and volume percentages of the minerals from the 17 different areas. These were calculated for 3 different scenarios: (1) the whole rock composition including serpentine (both associated with olivine alteration and the groundmass matrix), (2) the groundmass composition including serpentine (only associated with the groundmass matrix) and (3) the groundmass composition excluding all serpentine (Fig. 3).
The $\mathrm{SiO}_{2}$ and $\mathrm{MgO}$ contents decrease notably when olivine and serpentine are removed from the rock composition. The $\mathrm{CaO}$ contents increase significantly (10.49 wt\% to $28.62 \mathrm{wt} \%$ ) due to the high contents of monticellite and apatite in the groundmass. The $\mathrm{H}_{2} \mathrm{O}$ content decreases significantly when the groundmass composition is calculated without serpentine $(6.02 \mathrm{wt} \%$ to $1.82 \mathrm{wt} \%$ ) (Fig. 3).

\begin{tabular}{|c|c|c|c|}
\hline Components & (1) & (2) & (3) \\
\hline $\mathrm{SiO}_{2}$ & 32.23 & 25.26 & 20.58 \\
\hline $\mathrm{MgO}$ & 34.11 & 21.90 & 15.18 \\
\hline $\mathrm{CaO}$ & 10.49 & 20.51 & 28.62 \\
\hline $\mathrm{Al}_{2} \mathrm{O}_{3}$ & 1.34 & 2.52 & 3.42 \\
\hline $\mathrm{Cr}_{2} \mathrm{O}_{3}$ & 0.87 & 1.66 & 2.31 \\
\hline $\mathrm{Fe}_{2} \mathrm{O}_{3}$ & 0.02 & 0.03 & 0.04 \\
\hline $\mathrm{FeO}$ & 7.39 & 7.27 & 7.99 \\
\hline $\mathrm{MnO}$ & 0.17 & 0.21 & 0.22 \\
\hline $\mathrm{NiO}$ & 0.19 & 0.08 & 0.05 \\
\hline $\mathrm{TiO}_{2}$ & 1.34 & 2.62 & 3.67 \\
\hline $\mathrm{Na}_{2} \mathrm{O}$ & 0.08 & 0.10 & 0.08 \\
\hline $\mathrm{Ce}_{2} \mathrm{O}_{3}$ & 0.05 & 0.10 & 0.14 \\
\hline $\mathrm{La}_{2} \mathrm{O}_{3}$ & 0.02 & 0.04 & 0.06 \\
\hline $\mathrm{Nd}_{2} \mathrm{O}_{3}$ & 0.02 & 0.05 & 0.07 \\
\hline $\mathrm{Nb}_{2} \mathrm{O}_{3}$ & 0.01 & 0.02 & 0.03 \\
\hline $\mathrm{Y}_{2} \mathrm{O}_{5}$ & - & - & - \\
\hline $\mathrm{SmO}$ & - & 0.01 & 0.01 \\
\hline $\mathrm{Pr}_{2} \mathrm{O}_{3}$ & 0.01 & 0.01 & 0.01 \\
\hline $\mathrm{Ta}_{2} \mathrm{O}_{5}$ & - & - & - \\
\hline $\mathrm{P}_{2} \mathrm{O}_{5}$ & 2.88 & 5.70 & 8.04 \\
\hline $\mathrm{ThO}_{2}$ & 0.01 & 0.02 & 0.03 \\
\hline $\mathrm{F}$ & 0.19 & 0.38 & 0.54 \\
\hline $\mathrm{Cl}$ & - & - & - \\
\hline $\mathrm{SrO}$ & 0.25 & 0.49 & 0.69 \\
\hline $\mathrm{BaO}$ & 0.14 & 0.27 & 0.39 \\
\hline $\mathrm{ZnO}$ & - & - & - \\
\hline $\mathrm{K}_{2} \mathrm{O}$ & 0.68 & 1.35 & 1.90 \\
\hline $\mathrm{CO}_{2}$ & 1.47 & 2.90 & 4.10 \\
\hline $\mathrm{H}_{2} \mathrm{O}$ & 6.02 & 6.48 & 1.82 \\
\hline Total & 100.00 & 100.00 & 100.00 \\
\hline
\end{tabular}

Fig. 3 Table showing the average of each element oxide wt\%. (1) Wt\% of each oxide in whole rock composition; (2) Wt\% of each oxide in groundmass including serpentine (only groundmass); (3) Wt\% of each oxide in groundmass excluding serpentine. (Marschall, H.R. and Miller, D.P. Personal Communitcation)

\section{Perovskite geochemistry and oxygen fugacity}

Perovskite crystallisation is controlled by the composition and temperature of the kimberlite liquid 
(not the $\mathrm{fO}_{2}$ of the magma) enabling the perovskite chemistry to provide insights into magmatic processes and the evolution of magma using LREE. The zoning patterns record compositional changes from the initial magma source and help constrain the modes of emplacement during ascent of kimberlite magma to the surface (Bellis and Canil 2007, refs. there in).

The cores of the zoned perovskite contain the highest amount of $\operatorname{LREE}^{3+}$ (particularly $\mathrm{Ce}^{3+}$ ) and $\mathrm{Na}^{+}$, while the rims show a large increase in $\mathrm{Fe}^{3+}$ and $\mathrm{Al}^{3+}$ and a decrease in $L_{R E E^{3+}}$ (Fig. 4). This is due to coupled substitutions influenced by $\mathrm{fO}_{2}$ on to the perovksite Asite, $\mathrm{Ca}^{2+}$, and the $\mathrm{B}$-site, $\mathrm{Ti}^{4+}$.

$$
\begin{aligned}
& 2 \mathrm{Ti}^{4+}=\mathrm{Fe}^{3+}\left(\mathrm{Al}^{3+}\right)+\mathrm{Nb}^{5+} \\
& \mathrm{Ca}^{2+}+\mathrm{Ti}^{4+}=\mathrm{LREE}^{3+}+\mathrm{Fe}^{3+}\left(\mathrm{Al}^{3+}\right)
\end{aligned}
$$

\begin{tabular}{ccccc}
\hline $\mathbf{W t} \%$ & $(\mathbf{1})$ & $(\mathbf{2})$ & $(\mathbf{3})$ & $(\mathbf{4})$ \\
\hline $\mathrm{CaO}$ & 34.53 & 36.02 & 36.80 & 37.63 \\
$\mathrm{TiO}_{2}$ & 53.97 & 54.68 & 54.93 & 54.46 \\
$\mathrm{Fe}_{2} \mathrm{O}_{3} *$ & 0.70 & 0.87 & 1.15 & 1.63 \\
$\mathrm{Ce}_{2} \mathrm{O}_{3}$ & 2.96 & 2.71 & 2.22 & 1.86 \\
$\mathrm{La}_{2} \mathrm{O}_{3}$ & 0.84 & 0.87 & 0.84 & 0.88 \\
$\mathrm{Nb}_{2} \mathrm{O}_{5}$ & 0.68 & 0.67 & 0.66 & 0.90 \\
$\mathrm{Nd}_{2} \mathrm{O}_{3}$ & 1.57 & 1.36 & 1.03 & 0.77 \\
$\mathrm{Na}_{2} \mathrm{O}$ & 0.88 & 0.66 & 0.45 & 0.36 \\
$\mathrm{Al}_{2} \mathrm{O}_{3}$ & 0.09 & 0.10 & 0.15 & 0.21 \\
$\mathrm{SrO} \mathrm{O}$ & 0.26 & 0.25 & 0.30 & 0.27 \\
$\mathrm{Pr}_{2} \mathrm{O}_{3}$ & 0.34 & 0.32 & 0.29 & 0.13 \\
$\mathrm{ThO}_{2}$ & 1.54 & 0.39 & 0.01 & 0.00 \\
$\mathrm{SmO}$ & 0.20 & 0.18 & 0.15 & 0.13 \\
$\mathrm{Ta}_{2} \mathrm{O}_{5}$ & 0.21 & 0.13 & 0.05 & 0.03 \\
$\mathrm{Y}_{2} \mathrm{O}_{3}$ & 0.00 & 0.01 & 0.01 & 0.02 \\
$\mathrm{SiO}_{2}$ & 0.01 & 0.02 & 0.03 & 0.01 \\
$\mathrm{MnO}$ & 0.00 & 0.00 & 0.00 & 0.01 \\
$\mathrm{MgO}$ & 0.03 & 0.02 & 0.03 & 0.04 \\
\hline $\mathbf{T o t a l}$ & 98.84 & 99.27 & 99.11 & 99.32 \\
$\mathbf{\Delta N N O}$ & -5.24 & -4.55 & -3.29 & -1.52 \\
\hline
\end{tabular}

Fig. 4 Representative compositional data for the zoned perovskite. (1) and (2) represent the cores of the perovskite; (3) and (4) represent the rims of the perovskite.

*Total Fe calculate as $\mathrm{Fe}_{2} \mathrm{O}_{3}$

Due to the correlation of $\mathrm{Na}^{+}$and $\mathrm{Ce}^{3+}, \mathrm{Na}^{+}$decreases from the core to the rim (Fig. 5). The amount of $\mathrm{Fe}^{3+}$ and $\mathrm{Nb}^{5+}$ within the cores remains constant as $\mathrm{Na}^{+}$ decreases. There is a sudden increase in $\mathrm{Fe}^{3+}$ in the rims as $\mathrm{Na}^{+}$continues to decrease, whereas the $\mathrm{Nb}^{5+}$ levels undergo very little change or remain constant.

The barren kimberlite shows evidence of bi-modal cores and a wide range of $\mathrm{fO}_{2}$, signifying the occurrence of magma mixing and different episodes of emplacement. The cores of the zoned perovskite are the most enriched and reduced part of the crystal. The rims are the most depleted and oxidised part of the zoned perovskite, proving to be more evolved than the (primitive) cores (Fig. 6).

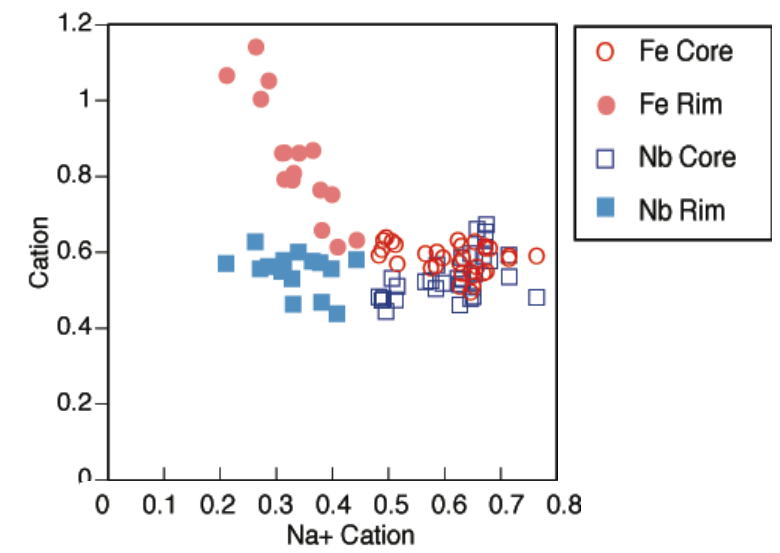

Fig. $5 \mathrm{Fe}^{3+}$ and $\mathrm{Nb}^{5+}$ vs. $\mathrm{Na}^{+}$. Hollow symbols are the cores and solid symbols are the rims. $\mathrm{Fe}^{3+}$ and $\mathrm{Nb}^{5+}$ are constant in the cores as $\mathrm{Na}^{+}$decreases. $\mathrm{Fe}^{3+}$ increases significantly in the rims, $\mathrm{Nb}^{5+}$ remains constant. There is some evidence of bi-modal cores.

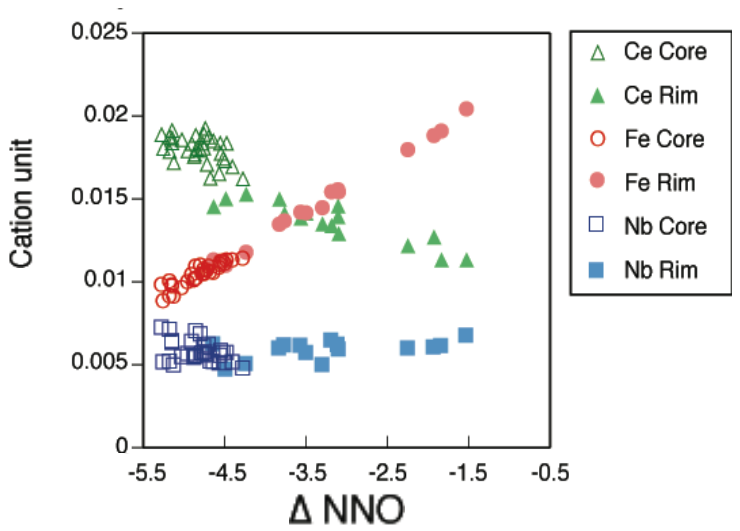

Fig. $6 \mathrm{Fe}, \mathrm{Nb}$ and $\mathrm{Ce}$ are in cations units per 3 oxygen vs. $\mathrm{fO}_{2}$. The data is split into the cores (hollow symbols) and rims (solid symbols) from the zoned perovskites. The cores are the most oxidised and the rims are the most reduced.

\section{References}

Bellis, A.J. and Canil, D. (2007). Ferric iron in $\mathrm{CaTiO}_{3}$ perovskite in as an oxygen barometer for kimberlite magmas I: Experimental Calibration. Journal of Petrography 48, $219-230$

Clement, C.R. (1982). A comparative geological study of some major kimberlite pipes in the Northern Cape and Orange Free State. Ph.D. thesis, Univ. Cape Town

Sparks, R.S.J., Baker, L., Brown, R.J., Field, M., Schumacher, J., Stripp, G. and Walters, A. (2006). Dynamical constraints on kimberlite volcanism. Journal of Volcanology and Geothermal Research $155,18-48$ 